\title{
Rita Horváth
}

\section{Stella and Rosa ${ }^{1}$}

The two connected short stories: "The Shawl" and "Rosa" were first published separately in 1980 and in 1983 and only in 1989 were they published together under the title "The Shawl." This title not only identifies the governing symbol of the two short stories but gives priority to the more obviously experimental work of art of the two. This short story marks a significant departure from the traditions of the Holocaust-literature, since non-survivors generally do not write directly about the inmates' experiences in the concentration camps ${ }^{2}$. The second, considrably longer novella: "Rosa" takes place in the terrain traditionally available to non-survivor artists, namely in post-Holocaust America. However, this short story for a brief peiod also crosses that border and writes directly about the Warsaw Ghetto.

As even the title of Cynthia Ozick's short story "Rosa" shows, the protagonist of the story is obviously Rosa Lublin, a survivor of the Holocaust ${ }^{3}$. However, in or-

\footnotetext{
${ }^{1}$ This essay was for publication by Alan Rosen (Bar Ilan University).

2 Breaking this tradition was the result of a long internal debate. The main stages of Ozick's inner fight, can be traced in her writings clearly. Amy Gottfried calls attention to the fact that "Ozick herself has long been concerned with the differences between recorded history and art, stating in 1969 that Jewish writers must 'retrieve the Holocaust freight car by freight car, town by town, road by road, document by document. The task is to save it from becoming literature." (Gottfried 40.) Ozick stated the next step of her struggle with herself at a roundtable discussion at a conference held in 1987: "Finally, about writing fiction. In theory, I'm with Theodor Adorno's famous dictum: after Auschwitz, no more poetry. And yet, my writing has touched on the Holocaust again and again. I cannot not write about it. It rises up and claims my furies. All the same, I believe-that the duty of our generation, so close to the events themselves, is to absorb the data, to learn what happened. I am not in favor of making fiction of the data, or of mythologizing or poeticizing it. [...] I constantly violate this tenet; my brother's blood cries out from the ground, and I am drawn and driven." (Lang 284.)

3 One certainly feels reluctant to use the term "survivor" describing Rosa after reading her opinion: "Consider also the special word they used: survivor. ...As long as they didn't have to say human being.
} 
der to understand this work of art one needs to examine closely the special lovehate-dependence relationship between the two Holocaust survivors: Rosa and Stella ${ }^{4}$. While analyzing the two short stories: "The Shawl" and "Rosa" together, one can see clearly that Stella is the real central figure of Rosa's life. For both of them the other has been especially important from the beginning. In their relationship Stella's original motives and needs were clear. She wanted to turn Rosa into her lost mother, but Rosa who was quite young herself (she was only twenty- three) and had been protected in all her life could not enter this role, although she fully realized Stella's need. However, she used her niece, the only living member of her family, as a special reference person. Sentences such as the following indicate this clearly:

Sometimes the electricity inside the fence would seem to hum, even Stella said it was only an imagining, but Rosa heard real sounds in the wire: grainy sad voices.

(9) [italics are mine]

Moreover, Rosa's ways to address her niece, the epithets and all the other words she uses in connection with Stella, reflect her ambivalent and extremely intensive feelings. She associates the very same words with Stella as with the other two people who evoke strong feelings in her: Magda and Dr. Tree. On the one hand, she calls Stella "Angel", "Dear one", "Golden", "Lovely", "Beautiful", etc. On the other hand, she uses the word "bloodsucker", her strongest and most accurate word to characterize Dr. Tree and his kind, also in connection with Stella.

Both of the short stories start with a name: "The Shawl" with Stella's first name and "Rosa" with the protagonist's full name. This, on the one hand, directs readers to pay close attention to both Stella and Rosa. On the other hand, it

It used to be refugee, but by now there was no such creature, no more refugees, only survivors. A name like a number..." However, I hope to use this word in an entirely different context.

4 "The Shawl" is an extremely intensive and complex work of art. Thus, there are numerous valuable approaches to the two connected short stories. The relationship between the two survivors has not been explored in depth yet. Alan L. Berger mentions one important aspect of this relationship: "By having both Stella and Persky insist that Rosa cannot live in the past, Ozick underscores not only the difference between survivors and refugees, but points out varying orientations amongst survivors themselves". (Berger 124.) However, he is mainly interested in exploring the Jewish images, tradition, and their significance in the two connected short stories, and placing them into the American Jewish Literature (Berger 52-54, 120-126.). Other scholars, such as Friedman (Friedman 16-17, 113-121.) and Kauvar are mainly interested in placing the two short stories into the context of Cynthia Ozick's oeuvre. Kauvar's analysis is especially illuminating concerning the Pagan and the Christian imagery of the two short stories (Kauvar 179-202.). 
emphasizes the utter difference between the two realms of reality: the world of the concentration camps and the world afterwards, since pieces of information such as family names are only important in a normal everyday world. ${ }^{5}$ However, this is merely one function of the extremely intense and multifunctional beginnings. Apart from the characters, the common imagery and symbols, etc., the opening of "Rosa" unifies the two short stories very effectively. Immediately the first sentence of the second short story tells the reader everything that has happened to Rosa since the closing scene of the first story. We gain the information that she survived the concentration camp, emigrated to the United States of America, became a shopkeeper, destroyed her own shop and moved to Miami. She is old now (later on one can calculate that the events of the second short story takes place in 1977), extremely unhappy and damaged. She cannot fit into the American society, but she fits in the stereotypical category of Holocaust survivors since she displays the most "obvious" features: she is a madwoman, a scavenger, who acts unpredictably, illogically and violently. Cynthia Ozick has a subtle, slightly ironic way of emphasizing Rosa's not fitting into the American society by saying in the second sentence that moving to Miami was a mad thing to do. An action which is so very natural for other elderly Jewish people is completely insane for her.

Already from the fourth sentence we learn that Stella has survived as well. The way the writer reveals this piece of information together with the title: "Rosa", and the opening words, make the reader aware that as far as this short story is concerned the central character is Rosa. The narrator talks about Stella at first in relation to Rosa: Rosa depends on her and she is Rosa's niece. At this point of the story even Stella's name is not mentioned.

The narrative technique employed by Cynthia Ozick has a very complex impact. The story is told from Rosa's point of view, it presents Rosa's mind, yet it is not told by employing first person narration. The fact that the story is told from the protagonist's point of view is emphasized powerfully by a device inherited from the modernists. Cynthia Ozick builds in phrases characteristic of the protagonist into the language of the narrator without indicating this with quotation marks. ${ }^{8}$ On the one hand, this special third person narration technique shows how deeply the writer is committed to her protagonist, in other words, she stands behind her firmly. Thus, by employing third person narration, the writer introduces a voice independent from Rosa

5 The exact degree to which Rosa and Stella are related to one another is another example of this kind of detail.

6 One of Joyce's major innovations is that he profiles his characters not only by their actual language use, but Joyce builds in phrases characteristic of them into the language of the third-person narration. Hugh Kenner calls this tricky device "uncle Charles Principle." "...the uncle Charles Principle: the narrative idiom need not be the narrator's." (Kenner, 18.) This device is highly confusing because Joyce never bothers to provide the reader with quotation marks. 
which takes all of her thoughts seriously, and by transmitting them faithfully, this narrative voice objectifies them to a certain degree. It seems to be a gesture, a way of not leaving the survivor alone, a way of creating a backing to her piercingly lonely voice. On the other hand, this way of narration leaves room, like the first person narration, for irony by rendering Rosa's views and understandings of the world, which are obviously not shared by the writer. It is so sad and ironic to realize how much prejudice against unassimilated Jews and against people from the lower classes Rosa brought with herself from home. One could find these disgusting remarks of hers about Yiddish, Hasidim, Judaism, peasants, working class people, etc. throughout the short novel. Undoubtedly the most hurtful point of the second short story, when Rosa, after talking to Mr. Finkelstein feels so triumphant: "She had no fear of Jews, sometimes she had-it came from her mother, her father-a certain contempt."

By forcing the reader to realize the limited nature of Rosa's understanding, the writer prepares the audience to be suspicious of Rosa's views concerning Stella. As the short story unfolds, Cynthia Ozick provides gradually all the necessary details to enable the reader to realize that Rosa in a peculiar way scapegoats Stella. She tries to escape from blaming herself by blaming Stella. Rosa embodies all her feelings of guilt in Stella. It is human, but of course so extremely unjust that she blames herself for her baby's death ( she did not take the risk of giving up Magda during the march, she went after the shawl which was inside the barrack instead of going after the loudly crying child in the arena and covering her mouth with her hands, she did not dare to run towards Magda, etc.). On the one hand, it is extremely painful for the reader to realize that the victim has a sense of guilt, on the other hand one has to see that blaming another victim is morally wrong. Thus, precisely Rosa's psychological self-protecting mechanism is the reason why Stella could not try Rosa's surviving strategy; Stella cannot remember, since then she would have to take responsibility for Magda's death. One of the most painfully ironic elements is that Rosa, who in the above described way took a considerable part in making Stella unable to remember, cannot forgive her for that. She can not forgive that her niece betrayed her by leaving her alone with their common past. She is unable to forgive that the very person who should understand her best and share her feelings, consciously has chosen not to. Rosa's intention for keeping Stella closely beside her was to prevent loneliness, to prevent complete isolation. This was a very natural expectation since the two women went through exactly the same hell together. Rosa even states this in one of her letters to Magda: "Stella was with me the whole time, she knows just what I know." However, Stella did not accept the role that Rosa wanted her to play. So much so, that she reminds Rosa that Magda is dead over and over, urges her to 
start a new life, and even buys her striped clothes as a birthday present. This is what the constant reference to Stella's coldness means. Thus, one aspect of the tragedy of the relationship of Rosa and Stella is that neither of the two women was able to accept the roles the other expected from her.

Literally, Rosa shifts all the responsibility over to her niece for all of her uncomfortable thoughts. Rosa is the one who knows that Magda is a child of rape committed by an SS man, but accuses Stella for having a "naturally pornographic mind." However, Rosa herself thinks that Persky stole her underwear.

However, there is a problem with the short story. In spite of the writer's traceable intentions to make the reader careful not to evaluate Stella and what she stands for with Rosa's bias, still, the short story communicates a message that there exists a "good" or at least an expedient way to deal with the trauma of the Holocaust taken by Rosa and a "bad", harmful way taken by Stella. One cause of this phenomenon is that in "Rosa" Cynthia Ozick defines two methods from which a survivor of the Holocaust can choose to fight for an acceptable human life "afterwards". These two methods mutually exclude one another.

The other cause is that Rosa's story has a "happy end," so it can be interpreted as a kind of success story. As opposed to this, Stella's life is shown as a stream of constant failure: She is an old spinster (49 years old) who cannot catch a husband although that is her main ambition. To trap a man is the main reason why she takes evening courses at New York University. She does not make enough money to feel safe. She looks exactly like an American-born person but she has a heavy accent. These troubles are inevitably real problems, in other words real indicators of failure in the eyes of any reader who accepts the American middle class value system. It also shows clearly how deeply Stella is damaged by her past and how obviously she displays the characteristics of a Holocaust survivor. Thus, the reader begins to feel that Stella's life is really a failure, versus Rosa's "success story," and at this point the reader naturally tries to find a reason for this.

The quite obvious answer is an ancient myth. This prefabricated thought which creeps in is that "suffering purifies", or rather consciously chosen and undertaken suffering purifies. The stories of Stella and Rosa suggest that if a person lets $\mathrm{him} /$ herself sink deeply, more precisely as deeply as is humanly possible into suffering, rage and insanity, then and only then he/she has a chance to come out of it at the end. The short story makes it also clear that this process is only effective if one takes all the suffering in entirely, sucks on it like the characters of Cynthia Ozick on the shawl, squeezes out every drop of its juice, gets stuffed with it. One must allow oneself to be filled up with it to the point when one becomes a mere container of pain,. until one can state "...Before is a dream. After is a joke. Only during stays. And to call it a life is a lie." Thus, part of the problem is that Rosa's surviving strat- 
egy is in harmony with our expectations, and Stella's goes against them. These expectations are set by the above described myth. The effect of this train of prefabricated thoughts is enhanced by another belief deeply rooted in the American society: a person whose life is obviously a failure (who is a "looser") has some kind of moral deficiency, he/she is somehow inferior to "winners."

Moreover, Stella's method is not well represented; the reader sees it only through the eyes of somebody who has tried the other way. We are never allowed to hear Stella speaking for herself. The only two occasions when we hear Stella's own voice are in connection with Rosa. Once we hear her voice literally, on the phone, powerless, sleepy, and in addition to all that, she speaks through electric wires, thus, she becomes one of those voices which even she herself thought to be unreal back in the camp. The other such occasion is her letter which should have been accompanied by Magda's shawl. This letter especially clearly reveals that Stella is convinced that the method one takes to win back one's "stolen" life is a result of a conscious choice ${ }^{7}$. That is the reason why she can ask Rosa to stop making herself crazy.

The view on insanity and constant suffering, which is suggested by Cynthia Ozick's short story, and which is supposed to prepare a way for some kind of recovery, is in such a sharp contrast with the general experiences of a lot of survivors, of their families, and of psychologists.: The Holocaust and all experiences in connection with it are so overwhelming that usually those who let insanity and pain possess them are not able to come out of that state again. On the other hand, those who keep themselves under strict control are able to lead a life which they can enjoy. ${ }^{8}$ Thus, it seems that Rosa's accusations according to which her niece tries to forget

7 Cynthia Ozick has a nicely subtle way of indicating the conscious nature of Stella's choice. Stella writes in her letter: "It isn't as if I don't know just exactly how you do it, what its like." This sentence, on the one hand refers to the scene of Rosa's worshipping the shawl, but on the other hand the word "it" can refer to the process of making oneself crazy.

8 "Forgetting, or rather not letting the Holocaust experiences enter one's consciousness, is a way of selfdefense" was the finding of several psychological researches. For example the researches carried out in the dream-laboratory of Haifa University. In addition to that, psychologists who work with Holocaust survivors are convinced, and psychological research showed it conclusively that the experience of the Holocaust is unique psychologically. Unique in the respect that one does not stand a chance to resolve it by bringing it up to one's consciousness and confronting it directly. Whereas, bringing up traumas to the patient's consciousness from his/her subconscious and enabling the patient to face and solve the various problems caused by traumatic experiences is the general method followed in psychotherapy. This usual method for Holocaust survivors not only ineffective, but expressly harmful, because remembering and thinking about their Holocaust experiences makes them ill. According to the experience of Péter Popper, the famous Hungarian psychologist, the behavior of those Holocaust survivors who threw themselves into hyperactivity and did not allow themselves to think about their immediate past proved to be the most successful. (Péter Popper's kind verbal help.) 
everything, cover a heroic attempt to control one's own life and not to let the past take over.

It is also crucial to understand why Persky is able to save Rosa. What is so special about him that enables this man to perform a miracle? Precisely this person, who has so many features that Rosa learnt at home to despise the most. He is an uneducated, old immigrant, whose family were not assimilated in Poland, who does not think much of philosophy, and does not speak English very well. On the other hand though, Persky is clever, funny, kind, self-confident, determined and patient. $\mathrm{He}$ frequently makes witty remarks such as "Only why backwards? I'm an application form? Very good. You apply, I accept." The only answer which is quite easy to prove from the text is a very natural one: He sees Rosa as a woman and this is exactly what she wanted for such a long time. Rosa, herself states this in another context, when she makes comments on Dr. Tree's letter: "They don't call you a woman anyhow." Rosa needed this the most since one of her most troubling problems is her identity. She feels that she has failed to fulfill the requirements of any roles or labels that have been offered to her, such as being a woman, a mother, a Jew, a Pole, an American, a witness, etc. There is something wrong with all of them. Either she was unable to identify herself with those roles or others could not do that.

Cynthia Ozick follows the process of Rosa becoming aware of her body and her appearance extremely delicately and sensitively. First she became embarrassed about her shoes: "Her shoes were not nice, she should have put on the other ones." Then she realized that "her dress was missing a button." She looked in the window of the cafeteria and fixed her hair. Even the writer's descriptions are getting more and more physical: "The air-conditioning was on too high, she felt the cooling sweat licking from around her neck down, down her spine into the crevice of her bottom." (These kind of bodily descriptions are in such contrast with the descriptions of the first short story, where the women's bodilessness, "their turning to air" were emphasized.) The last phase of Rosa's feminine metamorphosis is that she prepares herself for the opening of the box of Magda's shawl as a woman going out for a date. She even puts make up on.

It is also nicely ironical that the event of Persky accosting Rosa, which seems so personal to Rosa and is so much needed by her, is obviously a much practiced routine of Persky. Practically, Cynthia Ozick gives a well-tried recipe how to get acquainted with a stranger in Florida. One can represent this routine of Persky in a chart: 
1, stores story (to mention Hitler and the public security is useful)

2, Does she have an accent?

\begin{tabular}{|c|c|}
\hline if YES & if NO \\
\hline \multicolumn{2}{|l|}{$a}$, \\
\hline $\begin{array}{c}\text { How strange life is! Europe / } \\
\text { Poland / Warsaw }\end{array}$ & $\begin{array}{c}\text { I am from Europe / Eastern } \\
\text { Europe }\end{array}$ \\
\hline $\begin{array}{c}\text { Imagine this, two people from ... } \\
\text { meet in Miami, Florida ... In } \\
1910 \text { I didn't dream of Miami, } \\
\text { Florida ... }\end{array}$ & $\begin{array}{c}\text { Imagine this, two people born so } \\
\text { far from each other meet in } \\
\text { Miami ... }\end{array}$ \\
\hline
\end{tabular}

3, Famous members of the family

Obviously, "Rosa" is an important work of art of the American-Jewish literature. It deals with topics that proved to be central to the American-Jewish consciousness. There are several themes appearing in "Rosa" besides the main ones which are major concerns of the works of for example Bernard Malamud and Isaac Bashevis Singer. Topics like Jewish anti-Semitism, the alienated relationship between parent and child (Just think about Persky and his son!), the terrible loss of the mother tongue for an immigrant who used to be an intellectual, etc. In fact, the writer seems to summon all the central topics of American-Jewish literature. In addition to that, Cynthia Ozick deliberately refers to great works of art, such as Rosa's obsessive letter writing points to Saul Bellow's Herzog, etc. Cynthia Ozick accomplishes something very important extremely subtly. By calling into play all the determining topics of American-Jewish literature and assigning central importance to the Holocaust she transfers the emphases of this literary tradition. Thus, the two short stories written by Cynthia Ozick, "The Shawl" and "Rosa" not only fit in smoothly to the main trend of the so called Jewish-American literature, but function as a statement that the Holocaust is the main concern of the American Jewish consciousness. This statement, since it is communicated by the work of art itself, is extremely powerful and influential. 


\section{BIBLIOGRAPHY}

Ozick, Cynthia: The Shawl. New York: Vintage International, 1990.

Berger, Alan L.: Crisis and Covenant: The Holocaust in American Jewish Fiction. Albany: State University of New York Press, 1985.

Friedman, Lawrence S.: Understanding Cynthia Ozick. Columbia, South Carolina: University of South Carolina Press, 1991.

Gottfried, Amy: "Fragmented Art and the Liturgical Community of the Dead in Cynthia Ozick's 'The Shawl" Studies in American Jewish Literature: New Voices in an Old Tradition. 13 (1994) 39-51.

Kauvar, Elaine M.: Cynthia Ozick's Fiction: Tradition and Invention. Bloomington, Indianapolis: Indiana University Press, 1993.

Kenner, Hugh: Joyce's Voices. Berkeley, Los Angeles, London: University of California Press, 1978.

Lang, Berel, ed: Writing and the Holocaust. New York, London: Holmes and Meier, 1988. 